RESIDENT

\& FELLOW

SECTION

Section Editor

Mitchell S.V. Elkind, MD, MS

Shiva Kumar R., MD

Keerthiraj B., MD

Chandrasekhran

Kesavadas, MD

Address correspondence and reprint requests to Dr. Shiva Kumar R., Department of Neurology, Sree Chitra Tirunal Institute for Medical Sciences and Technology, Trivandrum 695011, Kerala, India drshivakumar1995@yahoo.co.in

\section{Teaching NeuroImages: \\ MRI in fibrodysplasia ossificans progressiva}
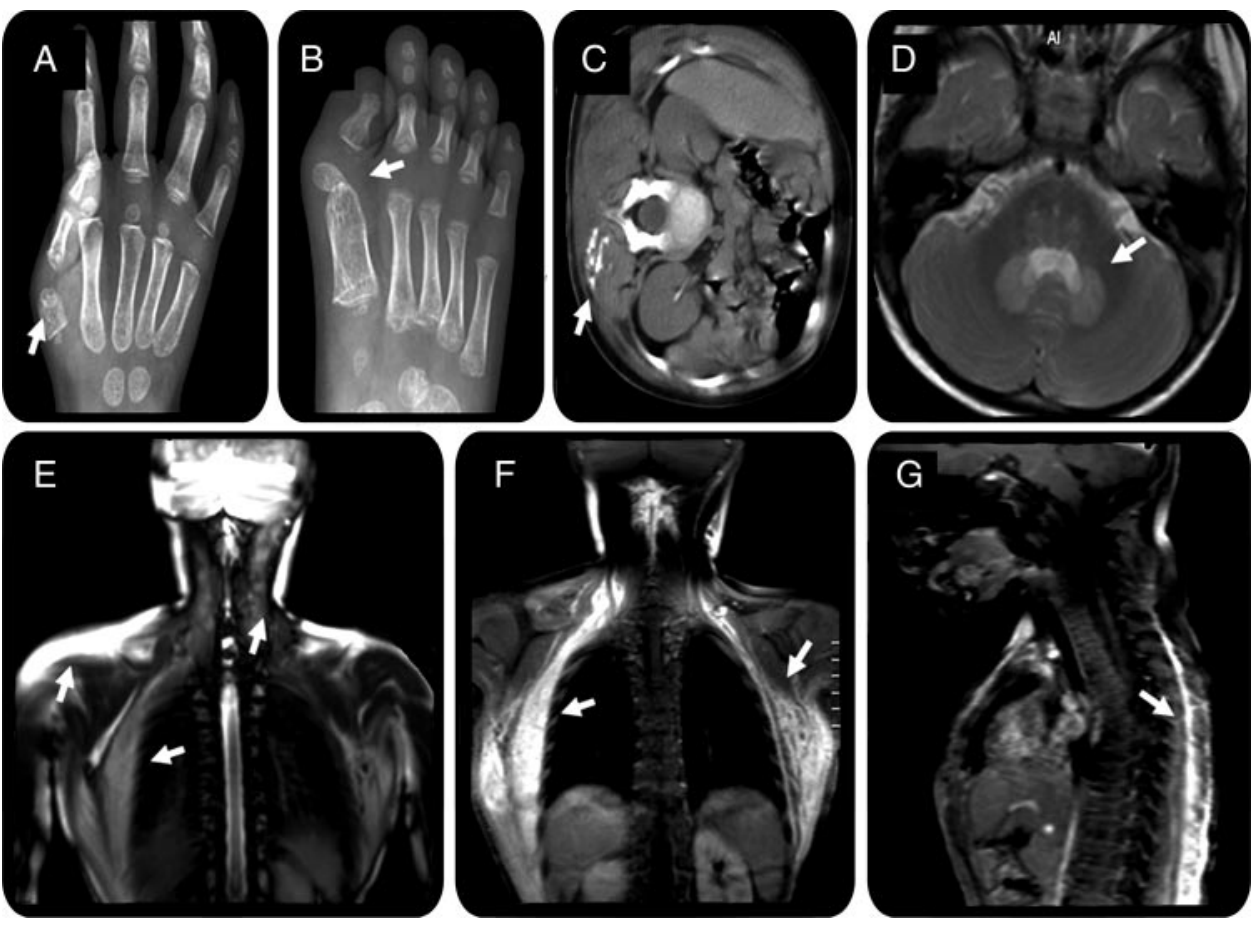

Skeletal X-rays show clinodactyly, short thumb, and metacarpals (A), and hallux valgus with short phalanx (B). The CT scan shows calcification around paraspinal muscles (C). T2-weighted MRI of the brain shows dentate nucleus hyperintensity (D); STIR-coronal MRI (E), T2-weighted (F), and postcontrast (G) show increased signal and contrast enhancement in the muscles and fascial planes of the thoracic wall and paraspinal muscles.

A 3-year-old boy presented with abnormal neck posturing and rapidly growing lumps over the neck. The presence of typical malformed great toes and ectopic calcification (figure, A-C) and an affected family member confirmed the diagnosis of fibrodysplasia ossificans progressiva (FOP). ${ }^{1}$ MRI of the cervicothoracic region (figure, $\mathrm{C}, \mathrm{E}-\mathrm{G}$ ) revealed diffuse hyperintense signals extending along the neck, thoracic wall, and paraspinal muscles. The presence of dentate nucleus hyperintensity on brain MRI indicates that FOP may not be purely a musculoskeletal disorder, but a multisystem disorder including CNS involvement (figure, D). There was pseudodystonia of the neck without any other neurologic signs. Because ec- topic ossification might not be present in the early stages, diagnosis of FOP based on radiographs alone may be delayed. In the presence of characteristic skeletal malformations, MRI can detect preosseous lesions and avoid additional diagnostic procedures, including biopsy. ${ }^{2}$

\section{REFERENCES}

1. Kaplan FS, Xu M, Glaser DL, et al. Early diagnosis of fibrodysplasia ossificans progressiva. Pediatrics 2008;121; e1295-e1300.

2. Merchant R, Sainani NI, Lawande MA, Pungavkar SA, Patkar DP, Walawalkar A. Pre- and post-therapy MR imaging in fibrodysplasia ossificans progressiva. Pediatr Radiol 2006;36:1108-1111.

From the Departments of Neurology (S.K.R.) and Imaging Sciences and Interventional Radiology (K.B., C.K.), Sree Chitra Tirunal Institute for Medical Sciences and Technology, Trivandrum, Kerala, India.

Disclosure: The authors report no disclosures. 


\section{Neurology}

\section{Teaching NeuroImages: MRI in fibrodysplasia ossificans progressiva \\ R. Shiva Kumar, B. Keerthiraj and Chandrasekhran Kesavadas \\ Neurology 2010;74;e20 \\ DOI 10.1212/WNL.0b013e3181cef7d1}

This information is current as of February 8, 2010

\section{Updated Information \&} Services

\section{References}

\section{Subspecialty Collections}

Permissions \& Licensing

Reprints including high resolution figures, can be found at: http://n.neurology.org/content/74/6/e20.full

This article cites 2 articles, 0 of which you can access for free at: http://n.neurology.org/content/74/6/e20.full\#ref-list-1

This article, along with others on similar topics, appears in the following collection(s):

All Genetics

http://n.neurology.org/cgi/collection/all_genetics

All Pediatric

http://n.neurology.org/cgi/collection/all_pediatric

Clinical neurology examination

http://n.neurology.org/cgi/collection/clinical_neurology_examination

MRI

http://n.neurology.org/cgi/collection/mri

Muscle disease

http://n.neurology.org/cgi/collection/muscle_disease

Information about reproducing this article in parts (figures,tables) or in its entirety can be found online at:

http://www.neurology.org/about/about_the_journal\#permissions

Information about ordering reprints can be found online:

http://n.neurology.org/subscribers/advertise

Neurology ${ }^{\circledR}$ is the official journal of the American Academy of Neurology. Published continuously since 1951, it is now a weekly with 48 issues per year. Copyright. All rights reserved. Print ISSN: 0028-3878. Online ISSN: 1526-632X.

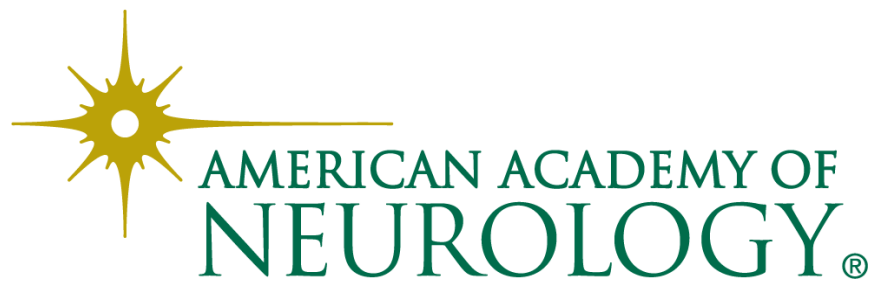

